\title{
Students' Assessment of the Translation Material in the Departments of English in Kurdistan Region- Iraq
}

\section{Vian Mikhail Poulis}

Department of English, College of Languages, Salahaddin University,Erbil, Kurdistan Region- Iraq.

E-mail: vivian.mikhael@uod.ac

\section{Wrya Izzadin Ali}

Department of English, College of Languages, Salahaddin University, Erbil, Kurdistan Region- Iraq.

E-mail: wryaizzadin@yahoo.com

\section{Abstract:}

Teaching material is considered a crucial element to the success of student achievement. This study aims to assess the effectiveness of teaching materials of translation courses offered to third- and -fourth year in the Departments of English from the students' perceptions. To achieve this, a questionnaire is used for data collection. This questionnaire is administered to (120) fourth-year students enrolled in the respective Departments of English of three Kurdistan Universities; (40) students from the University of Sulaimani, (40) students from Salahaddin University-Erbil, and (40) students from the University of Duhok, to find out the extent to which students are satisfied with the current translation materials offered in their departments. The data of the study are analyzed via (SPSS) using descriptive statistics. Accordingly, findings have shown that the students are unsatisfied with many aspects of the translation teaching materials, such as a lack of balance among translation theories, methods, procedures, and the text types. Additionally, little attention is given to the cultural aspects in raising students' cultural awareness, and there is a lack of coherence between the translation materials of thirdand fourth-year. Thus, a need for developing textbooks for translation courses in the Departments of English is recommended.

Key Words: Translation Material, Translation Teaching, Students' Assessment. 


\section{Introduction:}

Teaching translation at the university level is still a contentious issue tackled by many scholars and writers. For some, translation competence is natural and cannot be taught in formal teaching. For others, meanwhile, academic translation teaching is the only chance for many students to get translation competence for their future careers. Keeping in mind such aims, students expect the teaching materials, including the theoretical content and text types, of translation courses to match their expectations to allow them to achieve their goals. As such, this is something that teachers should consider in designing their courses. In other words, teachers/trainers have to think about the needs of their students, their translation competence, objectives or learning outcomes, methodology, as well as assessment and evaluation to integrate such into the content of the course (Kelly 2005). In the Kurdistan region, translation is offered in two departments: The department translation of Translation which offers specialized translation courses, and the department of English which offers translation courses to third- and fourth-year students as part of the language teaching curriculum. The latter is the concern of this study, i.e. translation courses offered to third-and fourth-year students in the Departments of English, Colleges of Languages at University of Sulaimani (UoS), Salahaddin University-Erbil (SUE), and University of Duhok (UoD). The problematic issue of these courses is that there is no specific translation textbook prescribed in these departments. Before 1991, textbooks that were proposed by the Iraqi Ministry of Higher Education and Scientific Research were used. However, after 1991, for social, cultural, economic, and cognitive reasons, the Ministry of Higher Education and Scientific Research in the Kurdistan Region of Iraq canceled these textbooks, seeing as they were designed to serve the Arabic context and not the Kurdish one. This is due to the fact that the residents of the Kurdistan Region are non-native speakers of Arabic. Since then, designing translation courses, including the teaching material and the course book (course plan), has become the teachers' responsibility.

\section{Research Aim}

This study aims to determine the effectiveness of the materials used in the translation courses offered in the Departments of English/Colleges of Languages at UoS, SUE, and UoD, per the assessment of the students in these educational institutions in the Kurdistan Region of Iraq.

\section{Research Question}

This study raises and seeks to answer this question:

To what extent are Kurdish learners satisfied with the current materials of translation courses offered in the Departments of English at UoS, SUE, and UoD? 


\section{Research Significance}

This study is of significance to translation teachers, course designers, and researchers. It is of value to teachers and course designers since the findings of this study can be a basis in restructuring and developing the materials for translation courses in the Departments of English. Meanwhile, considering the insufficiency of existing research in this area, the findings can also assist future researchers on translation material and students' assessment.

\section{Literature Review}

Teaching material is defined as a textbook, an institutionally prepared material, or a teacher's material. It is considered an essential component in the teaching and learning process. Teaching materials are classified into (a) printed materials, such as books, workbooks, worksheets; (b) non-print materials, such as audio-visual materials, videos, or computer-based materials; and (c) materials that comprise both print and non-print sources, such as self-access materials and materials on the Internet. In addition to the foregoing, there are also other kinds of materials that are not designed for instructional use, as in the case of magazines, newspapers, and TV materials (Richards 2001).

Per Richards' classification, the translation materials in the Departments of English in the Kurdistan Region understudy are mostly teacher's prepared materials, seeing as their preparation is the teachers' responsibility. In reassessing the translation program from the teachers' perspective in the Department of Translation at Salahaddin University-Erbil, Omer (2012) pointed out that teachers "were all free to choose the texts and did not have a list of text yard" (p. 35). Thus, many teachers use printed and non-printed material in translation courses. The former refers to handouts and texts to be translated, while the later covers audio-visual materials.

Before deciding the course content, teachers have to consider the context of the course and the type of translation competence and sub-competence they intend their students to achieve by the end of the course. Kelly (2005) highlighted the importance of the context in which teaching or training takes place in designing the course content. She indicated that some factors have a significant impact on deciding the course content such as "academic versus vocational contexts; undergraduate versus postgraduate models; a level of specialization, and core content" (p.61). Kelly added that common subcompetences, reflecting on translation course content at an undergraduate level around the world, should be taken into consideration for designing each course such as language competence, cultural competence, instrumental competence, professionalization, interpersonal competence, subject area competence, attitudinal competence, and unitization competence. 
When developing a translation material, Gabr (2001) maintained that teachers have to consider translation theory and practice to achieve the course goals. In the same vein, Ardi (2012) argued that the curriculum should include a particular subject on translation theory to "support the students to build their translation competence especially the sub-competence of knowledge of translation" (p. 327). Besides the theoretical fundamentals in each teaching unit, Sevilla, et al. (2003) added that there should be plenty of tasks to effectively help students acquire special skills (as cited in Jordan-Núñez, 2014).

Yunli (2017) considered cultural aspects as crucial in developing translation material since translation is a cultural activity. So, teachers should introduce the knowledge of cultural comparison and contrast consistently. He continued his discussion by saying that "the systematically well scheduled cultural introduction can help translation learners to acquire linguistic knowledge" (p.43). Consequently, this will raise their cross-cultural communicative competence which is an essential element in foreign language teaching. It is apparent that Yunli considered cross-cultural competence and linguistics competence the core of translation teaching. González Davies and Scott-Tennent (2005), meanwhile, found that in structuring translation materials, teachers should provide students with the translation strategies and procedures focusing on the cultural aspects, "learning materials can be designed to develop their cultural translation competence and awareness of strategies and procedures." (para. 8)

To highlight the importance of the translation materials, Bell $(1994$, p. 69) focused on the following:

1. Materials should be authentic when selecting texts and tasks, which will be a great help for the students if they face real-world texts and tasks.

2. Materials should stimulate interaction. If students are accustomed to discussing translation problems in class, they will likely be more critical in evaluating their translation when they work as translators.

3. Materials should allow students to focus on the formal aspects of the language. Therefore, students should be trained to decide how they should restructure the same message in different styles.

4. Materials should encourage students to develop learning skills and skills in learning how to learn. For instance, when discussing the assignments in the class, they must provide students with efficient translation strategies, e.g., how to cope with the problem of long sentences or how to choose words.

5. Materials should encourage students to apply their knowledge to work as translators. It is supposed that students will know how to deal with problems of translation after they finish the course. 
6. Materials and the teaching methodology are used with the goal that students are ready to become translators after they take the course.

The literature review showed that the text types comprise the core of the translation material. In the environment of translation courses, many text types are used to train students to translate from the source language (SL) to the target language (TL), and vice versa. For Hatim and Mason (1990), text types are considered as "a conceptual framework which enables us to classify texts in terms of communicative intentions serving an overall rhetorical purpose" (p. 140). Reiss (1976, as cited in Puchala 2011, p.363) divided text types and approaches into the following categories:

1. Informative texts which aim to convey information and facts. According to Nida's formaldynamic equivalence approach, and Newmark's communicative approach, these types of documents can most likely be translated.

2. Expressive texts which focus on the aesthetic style that aims at conveying images and emotions through the language of the text. It is better to handle this text type semantically and formally staying as close as possible to the author.

3. Operative texts concentrate on the persuasive language that aims to alter certain behaviors or views. Nida's dynamic equivalence approach is preferred to be used with operative texts to produce a better translation that will transfer more communicative messages created by the author.

Kelly (2000) recommended to use informative texts more than expressive ones in the early stages of teaching translation, clarifying that text selection is very crucial in the teaching activity. Sevilla et al. (2003) argued that selecting the texts for translation exercises should depend on the following criteria: (1) texts should come from a real source and be able to become translation projects; (2) texts should be complete; (3) texts should be varied in terms of subject matter, type, and degree of specialization; and 4) texts should be within the students' ability to translate since a text of excessive difficulty lacks pedagogical value ( as cited in Jordan-Núñez 2014, p. 98). Moreover, Hurtado (1999) asserted that selecting the text to be translated should be aligned with the decided objective, translation task, and the method of evaluating the results (as cited in Jordan-Nuñez 2014).

It is better for teachers to start with the topics that students are already familiar with to make the translation process more accessible, considering that doing so would allow students to find thematic information for understanding the texts. Additionally, attention should be given to the level of linguistic and terminological difficulty of the text to make the task easier for students. Besides, students have to be familiarized with the demands of the labor market (Orozco, 2003, as cited in Jordan-Núñez 2014). In her discussion of topics selected for the students, Orozco did not assign a role for students to share 
with their teachers in this process, whereas Biçer (2002) asserted that students should take part in the selection of texts that they translate under the guidance of their instructor. It is evident from the discussion that Orozco's (2003) point of view leans towards a teacher-centered approach, while Biçer (2002) supported a student-centered approach since the latter pays greater emphasis on involving students in the text-selection process.

Dagilienè (2012) argued that to expose learners to various aspects of a foreign language, "the material for teaching translation should be interesting, expressive, related to the learners' knowledge [...], authentic, and diverse in terms of structure and function" (p. 125). Dagilienè added that "While selecting the material, the potential for encouraging discussion is also very important. Translation texts should lead to discussion" (p.126). Such material encourages students in the classroom to discuss their ideas and compare their translation with their classmates. Here, the teacher's task is to be a facilitator who assesses student needs and selects material to illustrate particular features of the language.

It is worth mentioning that recent attention has been paid for the evaluation of the translation curriculum. For instance, Gabr (2002) investigated translation teaching at the national Egyptian universities; Mahasneh, (2013) evaluated the translation programs at the Master's level in Jorden; Kaveh and Karimnia (2015) assessed the quality of the Translation Studies Program at M.A level in Islamic Azad University of Iran. These studies concentrated on evaluating the translation programs that offer specialized translation courses on B.A. and M.A. levels. They referred to assess the materials of the courses, as a whole, within the curriculum evaluation. Whereas, in foreign language programs, teaching material was evaluated within the other components of translation course design, such as course objectives, methods, activities, assessment and evaluation. For example, Lei (1999) analyzed the status of translation teaching in China from different angles, including translation material. He indicated that many teachers published different textbooks of translation from English into Chinese and vice versa, to be used for non- departmental translation courses. Lei criticized these textbooks for being old and incomplete, illustrating word and sentence translation but not paragraphs and the entire text, and including a comparison between texts and translation of various styles. In a recent study conducted by Zhou and Zou (2017) to survey students' translation competence of non-English majors at Leshan Norma University, students assessed the translation material within the evaluation of the whole course. Findings showed that English as a Foreign Language (EFL) teachers should present a diverse range of materials in teaching translation to enrich their students' knowledge.

Literature has revealed that there is limited research on assessing the translation material offered in the Departments of English. Accordingly, this paper responds to the insufficiency of research in this particular area. 


\section{Methodology}

\section{Population and Sample of the Study}

This work is a part of an ongoing Ph.D. study. It has been carried out during the academic year 2017-2018 in the Departments of English/Colleges of Languages at UoS, SUE, and UoD in the Kurdistan Region-Iraq. The population of this study consists of (308) fourth-year students enrolled in the above-mentioned departments. The sample comprises (120) students chosen randomly; (40) students from UoS, (40) students from SUE, and (40) students from UoD. The rationale behind choosing the sample from fourth-year students was that they have already taken the third- and fourthyear translation courses, both from English into Kurdish and vice versa. Therefore, these students are qualified to judge the effectiveness of teaching materials since they are considered the culmination of the translation courses in the above-mentioned departments.

\section{Data Collection Tool}

To fulfill the aim of this study, the researchers designed a quantitative questionnaire to assess the suitability and efficiency of the current materials of the translation courses offered to third-and fourth-year students in the Departments of English, as viewed from the students' perceptions. The questionnaire consisted of (23) close-ended main items, (including the sub-items in items number. 5, 8,11 ), with a five-point Likert scale (5 strongly agree, 4 agree, 3 neutral, 2 strongly disagree, 1 disagree) (see Appendix).

\section{Validity and Reliability of the Tool}

The face validity of the questionnaire was obtained by submitting it to thirteen (13) jury members for judging the suitability of the items. To check the clarity and suitability of the items and estimate the required time, a pilot administration of the questionnaire was conducted on a sample of thirty-five (35) fourth-year students from SUE and UoD. Students showed that the items were clear and the time required to respond to the questionnaire was approximately (10-15) minutes. The reliability of the questionnaire was then obtained by using Cronbach's alpha formula. The coefficient reliability was found out to be at 0.95 , indicating reasonably high reliability according to Mehrens and Lehmann (1991).

\section{Administration of the Tool}

After ensuring the validity and reliability of the questionnaire, it was administered to (120) fourth-year students from UoS, SUE, and UoD by the end of the second semester of the academic year 2017-2018, from $26^{\text {th }}$ April to $8^{\text {th }}$ May 2018. The study was conducted at this time so that the students could be more objective while assessing the materials of the translation courses based on their 
experiences. For ethical purposes, the researcher consulted the administration and the responsible staff in each department and obtained their permission first. Afterward, the questionnaire was administered to the students during their class time, after highlighting the anonymity and the confidentiality of the information in the questionnaires.

\section{Results}

To answer the research question, which states 'To what extent are Kurdish learners satisfied with the current materials of the translation courses offered in the Departments of English at UoS, SUE, and UoD?', the results of the students' questionnaires were analyzed statistically by using SPSS, including mean (M), standard deviation (SD), and weighted percentile (WP). To find the verification level of the items, the cut score was used, through which the researchers asked (10) teachers with experience in teaching translation in the Departments of English to provide an average for a successful translation course. After calculating their scores, it was found out that the cut score is about 3.5. Thus, the results were classified into two categories: those items which achieved 3.5 and above were considered (above the cut score), while those items below 3.5 were considered (below the cut score). All items in the questionnaire (see Appendix) were organized in descending order, starting from the highest rank to the lowest one, as illustrated below in Table (1):

Table (1)

Ranking of Items According to Mean Scores, standard deviation, and Weighted Percentile

\begin{tabular}{|c|c|c|c|c|c|c|}
\hline S/No. & Items & \multicolumn{2}{|c|}{$\mathbf{M}$} & SD & WP & Rank \\
\hline \multirow[t]{5}{*}{8.} & $\begin{array}{l}\text { The courses' materials are structured to improve your skills in } \\
\text { translating: }\end{array}$ & & \multirow[t]{5}{*}{3.602} & \multirow[t]{5}{*}{.759} & \multirow[t]{5}{*}{$72.04 \%$} & \multirow[t]{5}{*}{1} \\
\hline & b. sentences. & 3.783 & & & & \\
\hline & a. phrases. & 3.691 & & & & \\
\hline & c. paragraphs. & 3.541 & & & & \\
\hline & d. long texts. & 3.391 & & & & \\
\hline 21. & $\begin{array}{l}\text { Videos and recordings are part of the materials to train you } \\
\text { for interpreting }\end{array}$ & & 3.533 & 1.302 & $70.7 \%$ & 2 \\
\hline \multirow[t]{7}{*}{5.} & $\begin{array}{l}\text { The courses' materials are structured to improve your skills in } \\
\text { the following areas of English: }\end{array}$ & & \multirow[t]{7}{*}{3.497} & \multirow[t]{7}{*}{.868} & \multirow[t]{7}{*}{$69.9 \%$} & \multirow[t]{7}{*}{3} \\
\hline & a. Vocabulary. & 3.808 & & & & \\
\hline & e. Reading comprehension. & 3.583 & & & & \\
\hline & d. Listening comprehension. & 3.441 & & & & \\
\hline & c. Speaking. & 3.425 & & & & \\
\hline & b. Grammar. & 3.400 & & & & \\
\hline & f. Writing. & 3.325 & & & & \\
\hline 14. & $\begin{array}{l}\text { Authentic texts are used in the translation courses such as } \\
\text { magazines, newspapers, formal documents, reports, } \\
\text { textbooks, etc. }\end{array}$ & & 3.425 & 1.026 & $68.5 \%$ & 4 \\
\hline 11. & $\begin{array}{l}\text { The courses' materials provide you with the following types } \\
\text { of texts to translate: }\end{array}$ & & 3.388 & .641 & $67.8 \%$ & 5 \\
\hline
\end{tabular}




\begin{tabular}{|c|c|c|c|c|c|c|}
\hline & a. General texts. & 3.916 & & & & \\
\hline & e. Political texts. & 3.508 & & & & \\
\hline & b. Literary texts. & 3.500 & & & & \\
\hline & d. Legal texts. & 3.466 & & & & \\
\hline & f. Journalistic texts. & 3.458 & & & & \\
\hline & g. Economic texts. & 3.216 & & & & \\
\hline & c. Scientific texts. & 3.050 & & & & \\
\hline & h. Sports texts & 2.991 & & & & \\
\hline 16. & $\begin{array}{l}\text { The courses' materials provide you with the strategies of } \\
\text { translation. }\end{array}$ & & 3.383 & 1.062 & $67.7 \%$ & 6 \\
\hline 19. & $\begin{array}{l}\text { The courses' materials provide you with good knowledge in } \\
\text { analyzing parallel texts- one in English and the other in } \\
\text { Kurdish. }\end{array}$ & & 3.383 & 1.054 & $67.7 \%$ & 6 \\
\hline 3. & $\begin{array}{l}\text { The courses' materials introduce you to the theories of } \\
\text { translation. }\end{array}$ & & 3.333 & .981 & $66.7 \%$ & 7 \\
\hline 4. & $\begin{array}{l}\text { The courses' materials provide you with different methods of } \\
\text { translation. }\end{array}$ & & 3.333 & 1.094 & $66.7 \%$ & 7 \\
\hline 17. & $\begin{array}{l}\text { The courses' materials enrich your knowledge in cohesion } \\
\text { and coherence. }\end{array}$ & & 3.325 & 1.062 & $66.5 \%$ & 8 \\
\hline 18. & $\begin{array}{l}\text { The courses' materials concentrate on improving your level in } \\
\text { revising and editing the final version of the translated texts. }\end{array}$ & & 3.291 & 1.079 & $65.8 \%$ & 9 \\
\hline 12. & $\begin{array}{l}\text { Specific criteria are followed in the selection of the courses' } \\
\text { materials. }\end{array}$ & & 3.266 & .905 & $65.3 \%$ & 10 \\
\hline 9. & The translation texts reflect the labor market needs. & & 3.225 & 1.111 & $64.5 \%$ & 11 \\
\hline 20. & $\begin{array}{l}\text { You get benefit from the content of the references mentioned } \\
\text { in the course books (courses' plans). }\end{array}$ & & 3.208 & 1.262 & $64.2 \%$ & 12 \\
\hline 2. & $\begin{array}{l}\text { The content description in the course books (courses' plans) } \\
\text { reflects the real content of the translation courses. }\end{array}$ & & 3.175 & .931 & $63.5 \%$ & 13 \\
\hline 6. & $\begin{array}{l}\text { The material of fourth year is complementary to the material } \\
\text { of third year. }\end{array}$ & & 3.175 & 1.261 & $63.5 \%$ & 13 \\
\hline 15. & $\begin{array}{l}\text { The translation texts are complete, not extracted from longer } \\
\text { texts. }\end{array}$ & & 3.158 & .9701 & $63,2 \%$ & 14 \\
\hline 22. & $\begin{array}{l}\text { The translation texts focus on the cultural aspects of both } \\
\text { English and Kurdish Languages. }\end{array}$ & & 3.158 & 1.181 & $63.2 \%$ & 14 \\
\hline 1. & $\begin{array}{l}\text { You have a clear idea about the courses content from the } \\
\text { beginning of the academic year. }\end{array}$ & & 3.150 & 1.097 & $63 \%$ & 15 \\
\hline 7. & $\begin{array}{l}\text { There is a balance in the courses' materials in terms of the } \\
\text { theoretical, practical, and technological aspects. }\end{array}$ & & 3.091 & 1.037 & $61.8 \%$ & 16 \\
\hline 13. & You participate in the selection of text types. & & 3.075 & 1.153 & $61.5 \%$ & 17 \\
\hline 10. & The courses' materials reflect the students' needs. & & 3.066 & 1.172 & $61.3 \%$ & 18 \\
\hline 23. & The texts given to be translated in the exams are difficult. & & 2.975 & 1.233 & $59.5 \%$ & 19 \\
\hline
\end{tabular}

Section one: It included 2 items. Their mean scores were between $(M=3.602-3.533)$ and a weighted percentile between ( $\mathrm{WP}=72.04 \%-70.7 \%)$. The verification level was above the cut score.

In this sense, item \#8 occupied the first rank since its mean score was $(M=3.602)$, with a standard deviation ( $\mathrm{SD}=.759)$ and a weighted percentile (WP=72.04\%). The mean scores of the sub-items were: 
$b(M=3.783), a(M=3.691), c(M=3.541)$, and d $(M=3.391)$. Students' responses revealed that the focus of the materials was on translating sentences, phrases, and paragraphs level more than the text level.

Item \#21 gained the second rank since its mean score was $(M=3.533)$, with a standard deviation $(\mathrm{SD}=1.302)$, and a weighted percentile ( $\mathrm{WP}=70.7 \%)$. The results of this item showed that the students agreed on that videos and recording materials were part of the contents to train students for interpreting.

Section two: It covered 21 items. Their mean scores were between ( $M=3.497-2.975)$, with weighted percentiles between $(\mathrm{WP}=69.9 \%-59.5 \%)$. The verification level was below the cut score.

Item \#5 obtained the third rank since its mean score was $(\mathrm{M}=3.497)$, with a standard deviation $(\mathrm{SD}=.868)$ and a weighted percentile $(\mathrm{WP}=69.9 \%)$. The mean scores of the sub-items were: $a$ $(\mathrm{M}=3.808), e(\mathrm{M}=3.583), d(\mathrm{M}=3.441), c(\mathrm{M}=3.425), b(\mathrm{M}=3.400), f(\mathrm{M}=3.325)$. Although the total mean score of the main item was below the cut score, the sub-items $i$ and $e$ obtained the level of above the cut score. The students' responses revealed that the materials of the translation courses were designed to improve vocabulary and reading comprehension more than the other skills.

Item \#14 occupied the fourth rank, since its mean score was $(M=3.425)$, with a standard deviation $(\mathrm{SD}=1.026)$ and a weighted percentile $(\mathrm{WP}=68.5 \%)$. The results indicated that the students provided a low level of satisfaction with that all the texts used in the translation courses were authentic texts.

Item \#11 obtained the fifth rank since its mean score was $(\mathrm{M}=3.388)$, with a standard deviation $(\mathrm{SD}=.641)$, and a weighted percentile ( $\mathrm{WP}=67.8 \%)$. The mean scores of the sub-items were: a ( $M=3.916)$, e $(M=3.508), b(M=3.500), d(M=3.466)$, f $(M=3.458), g(M=3.216)$, c $(M=3.050), h$ $(\mathrm{M}=2.991)$. The results revealed that the translation materials were designed to focus on the general texts, political texts, literary texts since the other text types achieved a low level of satisfaction.

Items \#16 and \#19 gained the sixth rank since their mean score was $(M=3.383)$, with standard deviations of both items ( $\mathrm{SD}=1.062 ; \mathrm{SD}=1.054)$, respectively, and a weighted percentile ( $\mathrm{WP}=67.7 \%)$. The results showed that the translation strategies and providing students with parallel texts did not get much attention in the translation content.

The seventh rank was obtained by two items, namely item \#3 and item \#4, which had the same mean score $(\mathrm{M}=3.333)$ and a weighted percentile ( $\mathrm{WP}=66.7 \%)$. The standard deviation of item \#13 is $(\mathrm{SD}=.981)$ and item \#14 is ( $\mathrm{SD}=1.094)$, respectively. The results indicated that students provided a low level of satisfaction with that the courses' materials provide them with different translation theories and methods.

Item \#17 gained the eighth rank since its mean score was $(M=3.325)$, with a standard deviation $(\mathrm{SD}=1.062)$, and a weighted percentile $(\mathrm{WP}=66.5 \%)$. The results revealed that the materials provided little information about cohesion and coherence, despite their importance in translation teaching. 
Item \#18 attained the ninth rank since its mean score was $(M=3.291)$ with a standard deviation $(\mathrm{SD}=1.079)$ and a weighted percentile $(\mathrm{WP}=65.8 \%)$. The results showed that the students provided a low level of satisfaction with that the courses' materials paid much attention to improving students' level in revising and editing the final version of the translated texts.

The tenth rank was occupied by item \#12 with a mean score $(M=3.266)$, a standard deviation $(\mathrm{SD}=.905)$, and a weighted percentile $(\mathrm{WP}=65.3 \%)$. The results indicated that little attention was paid to follow criteria when selecting the translation materials were selected.

Item \#9 obtained the eleventh rank since its mean score was $(M=3.225)$, with a standard deviation $(\mathrm{SD}=1.111)$, and a weighted percentile ( $\mathrm{WP}=64.5 \%)$. The results showed that students provided a low level of satisfaction with that the market needs were reflected in their courses' materials.

Item \#20 occupied the twelfth rank since its mean score was $(M=3.208)$, with a standard deviation ( $\mathrm{SD}=1.262)$ and a weighted percentile ( $\mathrm{WP}=64.2 \%)$. The results indicated that the students got little benefit from the sources mentioned in the course books.

The thirteenth rank was occupied by items \#2 and \#6. They shared the same mean score $(\mathrm{M}=3.175)$ and a weighted percentile ( $\mathrm{WP}=63.5 \%)$, with standard deviations ( $\mathrm{SD}=.931$ and 1.261), respectively, The results indicated that the students reported a low level of satisfaction with that the content described in the course books reflected the real contents of the courses, and the material of the fourth-year course was complementary to the material of the third year.

Items \#15 and \#22 gained the fourteenth rank. They shared the same mean score $(M=3.158)$ and a weighted percentile ( $\mathrm{WP}=63.2 \%$ ), with standard deviations $(\mathrm{SD}=.9701$ and 1.181), respectively. These results showed that most of the texts were not complete and they were extracted from longer texts. Additionally, the texts that were given for assignments and homework were not difficult.

Item \#1 attained the fifteenth rank since its mean score was $(M=3.150)$, with a standard deviation $(\mathrm{SD}=1.097)$ and a weighted percentile $(\mathrm{WP}=63 \%)$. Results showed that the students provided a low level of satisfaction with that they had clear idea about the content of the translation courses from the beginning of the year.

Item \#7 obtained the sixteenth rank since its mean score was $(M=3.091)$, with a standard deviation of $(\mathrm{SD}=1.037)$ and a weighted percentile $(\mathrm{WP}=61.8 \%)$. The results showed that the students provided a low level of satisfaction with that there was little balance in the theoretical, practical and technological aspects in the content of the translation courses.

Item \#13 occupied the seventeenth rank since its mean score was $(\mathrm{M}=3.075)$, with a standard deviation of $(\mathrm{SD}=1.153)$ and a weighted percentile $(\mathrm{WP}=61.5 \%)$. The results indicated that the students had little part in the selection of the texts and the content of translation courses.

Item \#10 gained the eighteenth rank since its mean score was $(\mathrm{M}=3.066)$, with a standard deviation $(\mathrm{SD}=1.172)$ and a weighted percentile $(\mathrm{WP}=61.3 \%)$. The results designated that little 
attention was given to the students' needs and interests in selecting the material/content of the translation course.

The nineteenth rank is occupied by item \#23 since its mean score was ( $M=2.975)$, with a standard deviation of $(\mathrm{SD}=1.233)$ and a weighted percentile $(\mathrm{WP}=59.5 \%)$. Although the mean score of this item was below the cut score level, it reflected positivity since the texts given in the exam were not difficult for many students. This indicated that the questions given in exams were covered in the translation materials.

\section{Discussion}

The current study aimed at determining the effectiveness of the translation materials, offered in the Departments of English, Colleges of Languages at UoS, SUE, and UoD, from the students' perceptions. The results reveal that $91.4 \%$ of the students are unsatisfied with the translation materials and $8.6 \%$ of them are satisfied, which is rather low. This is an indication of that the translation materials are beyond most of the students' expectations.

The results of this study are in line with those obtained by Kaveh and Karimnia (2015), who found out that "many of TS students at IAU branches are not satisfied with the materials because of different reasons" (p.28). The results, also, support those gained by Mahasneh's (2013), who concluded that "students were not fully satisfied with teaching methods and materials used" (p.185). Additionally, the same findings support those attained by Gabr (2002), who mentioned that "the students are not satisfied with the adequacy of the content of the translation classes, [and] translation teachers do not follow a systematic approach in developing their instructional objectives and selecting class material" (p.10).

The results of the questionnaire reveal that the focus of the teaching materials is on the simple units more than the complex ones. This might be to enhance the students' linguistic competence. Also, most of the students are satisfied with that videos and recorded materials are part of the translation courses to train students for interpreting. Here, teachers should clarify that the purpose of using these materials in the Departments of English is not to prepare students for a career in interpreting. This is not in line with Kelly (2005), who assures the importance of the context in developing the course materials and content.

What's more, the most positive results are found in improving vocabulary and reading comprehension items, while the least positive results are recorded in connection with listening, speaking, grammar, and writing. Additionally, translation materials do not enrich students' cohesion and coherence knowledge. This indicates that translation courses at the Departments of English lean more towards improving the receptive skills rather than the productive ones. 
Besides, students' responses indicate that most of the texts used in the translation courses are unauthentic, and the cultural aspects receive little attention to be highlighted in the translated texts. The results also reveal that translation theories, methods, procedures, and strategies, which are essential elements in acquiring translation competence, receive little attention in the teaching materials. This is not in accordance with González Davies and Scott-Tennent's (2005) opinions that "learning materials can be designed to develop [students'] cultural translation competence and awareness of strategies and procedures." (para. 8), and " "theory will support the students to build their translation competence" (Adri, 2012, p. 327)

Moreover, the obtained data reveal that the selection of courses' content is not based on specific criteria. Also, market needs and student needs are not considered in the content of the translation courses adequately. Also, students have little role in the selection of text types of translation courses. This is not in line with Biçer (2002), who asserted that students should take part in the selection of texts that they translate under the guidance of their instructor.

Furthermore, students' results indicate that there is no coherence between the materials of translation courses; The material of the fourth year is not complementary to the material of the third year. This contradicts with Kelly (2000), who pointed out that "it is easier for students to develop the competences necessary to undertake different translation commissions if there is a certain continuity in the subject matter or field dealt with over a period of time" (p.160).

\section{Conclusion:}

Effective teaching and learning of translation hinges on the effective use of teaching materials. This study elicits the students' perceptions in assessing the teaching materials of the translation courses in the Departments of English at UoS, SUE, and UoD. Based on the students' views, the current translation materials offered to third-and-fourth year might be a resource for students' vocabulary enrichment and reading comprehension. However, the materials do not meet students' needs and market needs. The students have expected these materials would improve their translation competence and sub-competence, their knowledge in text analysis, translation theories, methods, strategies, cultural aspects, coherence, cohesion, revising, editing, but they have been beyond their expectations. It seems that there is a lack of coordination between the course objectives and materials selection, which leads to the inadequacy of teaching materials. Therefore, there is a necessity for cooperation among the three Kurdistan universities to develop textbooks and integrate them with the course objectives, sequencing, teaching methods, and evaluation to serve the needs of translation courses at the Departments of English understudy. 


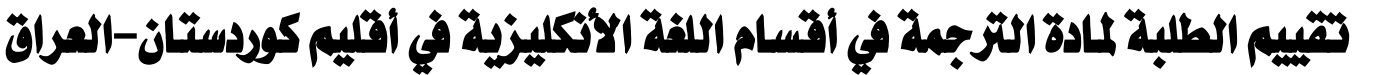

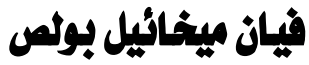

لـــسم اللغة الأنكليزية، كلية اللغات، جامعة صلاح الدين، اربيل، أقليهم كرد ستان، العراق. vivian.mikhael@uod.ac : البريد الإلكزوني

\section{لـوريا مز اللدين علي}

لــقسم اللغة الأنكليزية، كلية اللغات، جامعة صلاح الدين، اربيل، أقليم كرد ستان، العراق. wryaizzadin@yahoo.com : البريد الإلكتزوني

تعتبر المادة التعليمية عنصرا أساسيا لنجاح انجازالطالب. تهدف هذه الدراسة إلى تقييم فعالية مواد تدريس كورسات التزجمة التي تدرس في المرحلة الثالثة والرابعة في أقسام اللغة الإنجليزية من منظور الطلبة. ومن أجل تحقيق هذا الهدف، تم استخدام الأستبيان الكمي لجمع البيانات. وقد تم تطبيق هذا الاستبيان على (120) طالب في المرحلة الرابعة في أفسام اللغة الإنكليزية المعنية في ثلاث جامعات في كوردستان ; (40) طالب من جامعة السليمانية و (40) طالب من جامعة صلاح الدين - أربيل و (40) طالب من جامعة دهوك، وذلك لمعرفة مدى قناعة الطلاب بمواد التزجمة التي تدرس في أقسامهم. وقد تم تحليل البيانات باستخدام الإحصاء الوصفي بواسطة برنامج (SPSS). وبناءُ على ذلك، أظهرت النتائج بعدم قناعة الطلبة حول العديد من الجوانب في مواد تدريس التزجمة، مثل عدم وجود توازن بين نظريات وأساليب واجراءات التزجمة وأنواع النصوص. بالأضافة الى قلة الأهتمام بالجوانب الثقافية لزيادة الوعي الثقافي لدى الطلاب، وعدم وجود ترابط بين مادتي التزجمة للمرحلتين الثالثة والرابعة. ولهذا توصي هذه الدراسة بضرورة تطوير كتب منهجية للتزجمة في أقسام اللغة الإنكليزية. الكلمات المفتاحية ؛ مادة الزجمة، تدريس التزجمة، تقييم الطلاب. 


\section{References:}

Ardi, H. (2012). Is theory of translation needed to build students' translation competence? Proceeding of international seminar on languages and arts: ISLA FBS Universitas Negeri Padang. 320-328. http://ejournal.unp.ac.id/index.php/isla/article/download/3988/3199. (Accessed 15th December 2018)

Bell, R. (1994). Translation and Translating. Longman Group UK Ltd.

Biçer, A. (2002). Teaching translation at English language teaching departments: Process approach vs traditional approach. Çukurova University, Department of English Language Teaching.

Dagilienè, I. (2012). Translation as a Learning Method in English Language Teaching. Studies About Languages, 0(21). http://dx.doi.org/10.5755/j01.sal.0.21.1469 (Accessed 18th June 2017)

Gabr, M. (2001). Toward a model approach to translation curriculum development. Translation Journal, 5 (2).

Gabr, M. (2002). Quality Assurance in Translator Training. Translation Journal, 6 (3). Available from: https://translationjournal.net/journal/21quality.htm.(Accessed 12th may 2017)

González Davies, M. and Scott-Tennent, Ch. (2005). A Problem-solving and student-centred approach to the translation of cultural references. Meta, 50 (1), pp. 160-179

Hatim, B \& Mason, I (1990). Discourse and the Translator. London, Longman.

Jordan-Núñez, K. (2014). Some tips for designing and lecturing an undergraduate course in economic, financial and commercial translation. In: M. Granat, (Ed.). Current trends in translation teaching and learning E, (Vol.1, pp. 83- 114). Department of Modern Languages and Contributors Editorial Review Board.

Kaveh, F. and Karimnia, A. (2015). Translation studies program evaluation at Master's Level in Iran: A study on Islamic Azad University curriculum design. Journal of Applied Linguistics. 1 (2), 21-30 
Kelly, D. (2000). Text selection for developing translator competence: Why texts from the tourist sector constitute suitable material. In: In C. Schaeffner \& B. Adab (Eds.) Developing Translation Competence, (PP. 157-167). John Benjamins.

Kelly, D. (2005). A Handbook for translator trainers: A guide to reflective practice. Manchester. St. Jerome Publishing.

Lei, Mu. (1999). Translation teaching in China. Meta, 441, 198-208.

Mahasneh, A. (2013). Translation training in the Jordanian context: Curriculum evaluation in translation education. published Doctorate Dissertation, Graduate School of Binghamton University, State University of New York

Mehrens, W. A. and Lehmann, I. J. (1991). Measurement and evaluation in education and psychology. Belmont CA: Wadsworth Thomson Learning.

Omer, Y. A. (2012). Reassessing translation training programmes in Kurdistan universities at undergraduate level: Towards a new model of translator training programmes. Unpublished Doctorate Dissertation. Aston University

Puchala, C. (2011). Text typology and its significance in translation. ZESZYT, 63, 357366. Seria Philologiczna Studia Anglia

Richards, J. C. (2001). Curriculum development in language teaching. Cambridge: Cambridge University Press.

Yunli, 2017. A Study of concrete cultural approaches in translation teaching. Cross-Cultural Communication, 13(8), 40-43. DOI:10.3968/9883

Zhou, Y. and Zou, L. (2017). Cultivation of translation competence-A Study on Translation Teaching in College English Teaching in Leshan Normal University, Sichuan, China. Journal of Language Teaching and Research, 8(4), 756-760. DOI: http://dx.doi.org/10.17507/jltr.0804.15 


\section{Appendix}

\section{Questionnaire}

Dear Student,

This questionnaire is a survey to assess the materials of third- and fourth-year translation courses. Kindly, read each of the following items carefully for accurate assessment, and then answer by ticking off $(\sqrt{ })$ to the relevant option.

(5= Strongly agree, $4=$ Agree, $3=$ Neutral, $2=$ Disagree, $1=$ Strongly disagree $)$

Please be assured that all the information you provide in your answers will remain confidential and will only be used for the purpose of the research I am conducting. Nobody else, either from inside or outside the department will be able to have access to such information. Thank you for taking the time to respond.

The researchers

\begin{tabular}{|c|c|c|c|c|c|c|}
\hline S / No. & Items & $\begin{array}{l}\text { Strongly } \\
\text { agree (5) }\end{array}$ & $\begin{array}{l}\text { Agree } \\
\text { (4) }\end{array}$ & $\begin{array}{l}\text { Neutral } \\
\text { (3) }\end{array}$ & $\begin{array}{l}\text { Disagree } \\
\text { (2) }\end{array}$ & $\begin{array}{l}\text { Strongly } \\
\text { disagree } \\
\text { (1) }\end{array}$ \\
\hline 1. & $\begin{array}{l}\text { You have a clear idea about the courses' content } \\
\text { from the beginning of the academic year. }\end{array}$ & & & & & \\
\hline 2. & $\begin{array}{l}\text { The contents description in the course books } \\
\text { (courses plans) reflects the real content of the } \\
\text { translation courses. }\end{array}$ & & & & & \\
\hline 3. & $\begin{array}{l}\text { The courses' materials introduce you to the } \\
\text { theories of translation. }\end{array}$ & & & & & \\
\hline 4. & $\begin{array}{l}\text { The courses' material/content provides you with } \\
\text { different methods of translation. }\end{array}$ & & & & & \\
\hline \multirow[t]{7}{*}{5.} & $\begin{array}{l}\text { The courses' materials are structured to improve } \\
\text { your skills in the following areas of English: }\end{array}$ & & & & & \\
\hline & a. Vocabulary. & & & & & \\
\hline & b. Grammar. & & & & & \\
\hline & c. Speaking. & & & & & \\
\hline & d. Listening comprehension. & & & & & \\
\hline & e. Reading comprehension. & & & & & \\
\hline & f. Writing. & & & & & \\
\hline 6. & $\begin{array}{l}\text { The material of fourth year is complementary to } \\
\text { the material of third year. }\end{array}$ & & & & & \\
\hline 7. & $\begin{array}{l}\text { There is a balance in the courses' materials in } \\
\text { terms of the theoretical, practical, and } \\
\text { technological aspects. }\end{array}$ & & & & & \\
\hline \multirow[t]{5}{*}{8.} & $\begin{array}{l}\text { The courses' materials are structured to improve } \\
\text { your skills in translating: }\end{array}$ & & & & & \\
\hline & a. phrases. & & & & & \\
\hline & b. sentences. & & & & & \\
\hline & c. paragraphs. & & & & & \\
\hline & d. long texts. & & & & & \\
\hline 9. & The courses' materials reflect the labor market needs. & & & & & \\
\hline
\end{tabular}




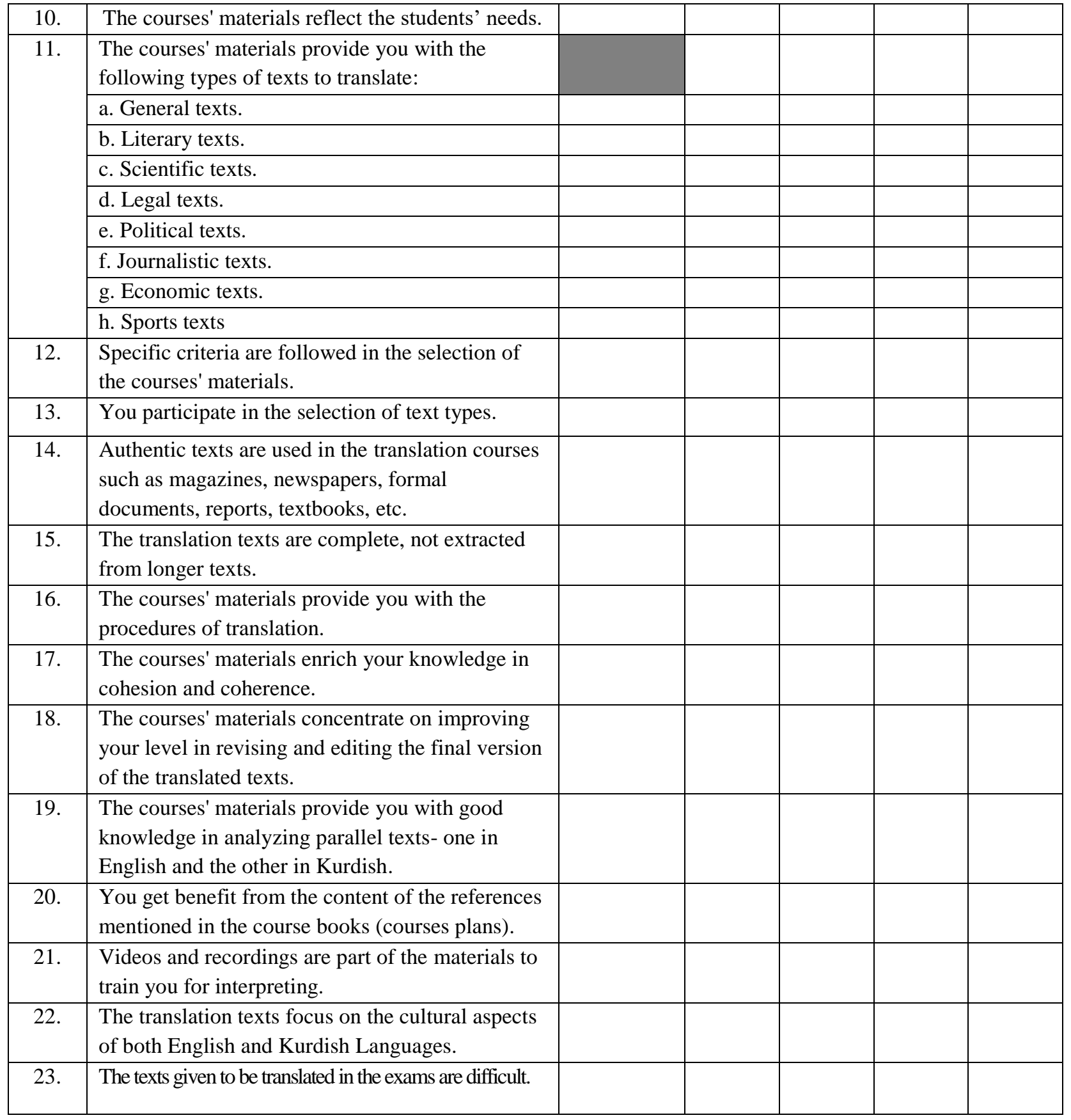

Thank You 